Weed Biology and Management 18, 184-196 (2018)

\title{
Effect of management practices for Stylosanthes hamata (L.) Taub. biomass cover on the weed species in different direct-seeding, mulch-based cropping systems
}

\author{
ABIB CAMARA $^{1,2 \star} \mathbb{D}$, ABDOULAYE DIENG $^{1}$, MAMADOU T. DIAW $^{1}$, GUY MER GEAI $^{2}$ and \\ JÉRÔME BINDELLE ${ }^{3}$ \\ ${ }^{1}$ National School of Agriculture, Thies-University, Thies, Senegal, Gembloux Agro-Bio Tech ${ }^{2}$ Laboratory of \\ Tropical Agroecology and Horticulture and ${ }^{3}$ Laboratory of Precision Livestock and Nutrition, Liege-University, Gembloux, \\ Belgium
}

\begin{abstract}
Weed management is a major challenge for smallholders' adoption of conservation agriculture techniques. The phytological composition and weed biomass in five direct-seeding cropping systems based on the millet-groundnut rotation, with permanent cover provided by Stylosanthes hamata (L.) Taub., were evaluated after 3 years in western Senegal. A transect was used to determine the phytological composition. The weed biomass was measured in five quadrats in the middle and at the end of the plant growth cycle. This study shows that $S$. hamata ground cover does not allow the effective control of weeds; high weed infestation was recorded in all direct-seeding cropping systems (58-75\% of the ground cover). A high diversity of weed species was observed in all treatments, dominated by Eragrostis ssp. and Dactyloctenium aegyptium Beauv. Cutting back and removing the aboveground biomass reduced the ground cover provided by $S$. hamata, lowered the weed species diversity and favored heliophilous species such as Eragrostis tremula but did not reduce weed infestation. Animal manure application did not, in the short term, affect the composition or structure of the weed species. However, it favored weed development and increased aboveground biomass. In the long term, this could affect weed seedbank and structure. Cutting back and removing the aboveground biomass of $S$. hamata resulted in lower weed diversity and higher crop yield. To achieve effective weed control, additional research on management techniques that would focus on the combination of cutting back vegetation and weeding along the crop seeding line will be needed.
\end{abstract}

Keywords: biomass, direct-seeding mulch, phytological composition, Stylosanthes hamata, weed.

\section{INTRODUCTION}

In sub-Saharan Africa, agriculture is facing several challenges related to production, the environment and the

Communicated by Md. Amzad Hossain

*Correspondence to: Abib Camara, National School of Agriculture, Thies-University, Km 3,5 Route de Khombole, PO Box A 296 Thies, Senegal.

Email:camouabib@yahoo.fr

Received 9 March 2016; accepted 5 June 2018

(C) 2018 Weed Science Society of Japan economy. Labor-intensive production systems with low input levels, using little fertilizer and/or phytosanitary treatments, predominate in these regions. But as a result of the soil exhaustion caused by the elimination of the fallow, these systems are no longer able to meet the population food requirements. To reverse this trend and enhance soil fertility and improve crop productivity, conservation agriculture (CA) is often promoted (Ito et al., 2007; Valbuena et al., 2012; Corbeels et al., 2014). Direct-seeding and no-tillage cropping systems 
are being developed to sustainably improve crop productivity and soil fertility (Odunze, 2002; Razafimbelo et al., 2006; Saito et al., 2010). These systems offer several advantages: they are less time consuming, require less arduous work, reduce weeding and improve crop yields (Odunze, 2002; Salako \& Tian, 2003). Conventional tillage contributes to soil degradation, particularly in tropical environments, by promoting the oxidation of organic matter (Johansen et al., 2012). However, tillage reduction or elimination is generally accompanied by increased diversity and higher levels of weed infestation in the absence of herbicide treatments (Zanin et al., 1997; Légère et al., 2005; Chauvel et al., 2011). In many cropping systems, ploughing is a weed control method (Ekeleme et al., 2005; Gruber \& Claupein, 2009). It buries weed seeds that are otherwise found on the surface. The evaluation of the weed seeds stock in the soil surface layer $(<5 \mathrm{~cm})$ by Mulugeta and Stoltenberg (1997) and Swanton et al. (2000) showed a greater amount of weed seeds in direct-seeding systems than in CA systems. Hani and Nawal (2005) even recommend deep ploughing in order to dispose of viable weed seeds. They lose their germination ability after being buried for a long period, particularly if they are lowdormancy seeds (Gruber \& Claupein, 2009). Burying seeds deep underground also prevents the germination of heliophilous species (Noba, 2002).

Weed management is a major challenge to the adoption of CA by smallholders. The reduction or elimination of ploughing must often be accompanied by an increase in the use of herbicides (Zanin et al., 1997; Ito et al., 2007; Johansen et al., 2012; Muoni et al., 2013). However, in sub-Saharan Africa, the low investment capacity of smallholders (Corbeels et al., 2014) and technical expertise required for the use of herbicides (Johansen et al., 2012) hinder the spread and adoption of chemical-based weeding techniques. Therefore, the adoption of CA technologies depends greatly on the farmers' weed control ability. Knowledge of weed population is important with regard to evaluating how much harm they can cause and to limiting their damaging effects on the crops. For this purpose, the weed floras associated with different millet (Pennisetum glaucum (L.) R.Br.) and/or groundnut (Arachis hypogaea L.) cropping systems, intercropping with Stylosanthes hamata (L.) Taub., have been studied. Millet and groundnut are the main crops grown in Senegal, and even throughout sub-Saharan Africa. S. hamata is an annual herbaceous plant of the Fabaceae family. It is used in many mixed crop-livestock systems as a cover crop and fodder. An intercropping system that will allow crop and forage production while maintaining soil fertility will present a considerable appeal to smallholders. However, for the adoption of that system, effective management techniques for weed control will have to be devised.

To design sustainable cropping systems through soil fertility and weed infestation management, an efficient and diversified production experiment based on several management approaches (crop rotation, intercropping, mulching, animal manure application and mowing aboveground biomass) was carried out over 3 years. This paper shows the results aiming to evaluate the diversity of weeds and the pressure they exert on different direct-seeded cropping systems under the permanent cover of $S$. hamata based on the traditional millet-groundnut rotation practiced throughout the Senegalese Groundnut Basin.

\section{MATERIALS AND METHODS}

\section{Experimental site}

The experiment was carried out on the experimental farm of the "École Nationale Supérieure d'Agriculture (ENSA)" in Thies $\left(14^{\circ} 45^{\prime}\right.$ lat. North; $16^{\circ} 53^{\prime}$ long. West) in Senegal. The site is influenced by the Sahelo-Sudanian climate. The rainy season ranges from July to October. The annual rainfall recorded in 2012, 2013 and 2014 was, respectively, $767 \mathrm{~mm}, 603 \mathrm{~mm}$ and $331 \mathrm{~mm}$.

The soil texture is sandy with low organic matter content $(1.53-1.84 \%$ C). A particle size analysis of the arable layer $(<20 \mathrm{~cm})$ indicates percentages of $89-91 \%$ sand, 5-6\% lime and 4-5\% clay. The Cation Exchange Capacity is between 2.09 and $2.16 \mathrm{meq} 100 \mathrm{~g}^{-1}$; the $\mathrm{pH}$ water ranged from 7.3 to 7.9 , and the $\mathrm{pH} \mathrm{KCl}$ was between 6.7 and 7.5 .

\section{Treatments and experimental design}

The experiment started in July 2012 and lasted 3 years. It focused on a comparison of five direct-seeding mulch-based cropping systems including $S$. hamata as a companion cover crop for the two main crops grown in rotation in Senegal: (i) $S$. hamata fallow in the first year, millet intercropped with $S$. hamata in the second year and groundnut in intercropped with $S$. hamata in the third year (SF-MS-GS); (ii) SF-GS-MS; (iii) GSMS-GS; (iv) MS-GS-MS; and (v) the MS-MS-MS rotation. The plots were divided into two from the second year onward to test the effect of manure application: (i) a subplot without application of manure (WAM); and (ii) a subplot with the application of manure (AM) at a dose of 10 tons $\mathrm{ha}^{-1}$ of raw material following the recommendations of Fernandes et al. (2000) for sandy soil in the area in the form of dried cow manure. Two methods for managing biomass 
cover were tested in the third year at the subplot level: (i) cutting back and removing $S$. hamata and weed biomass 60 days after sowing the millet and groundnut; and (ii) no cutting back or removal of cover or weeds before the millet or groundnut was harvested. The different manures used in the second and third years had respective $\mathrm{pH}$ values of 7.62 and 7.73 , and the chemical compositions for years 2 and 3, respectively, were: humidity (27.31 and 28.75\%), total ash (36.45 and $48.28 \%$ of dry matter - DM), C (30.93 and $26.24 \%$ of $\mathrm{DM}), \mathrm{N}$ (2.44 and $1.64 \%$ of DM), Ca (6.02 and $4.25 \mathrm{~g}$ $\mathrm{kg}^{-1}$ of DM), $\mathrm{Mg}$ (2.47 and $0.24 \mathrm{~g} \mathrm{~kg}^{-1}$ of DM) and P (111 and $132 \mathrm{~g} \mathrm{~kg}^{-1}$ of DM). The 20 compared treatments were set up in the field using a randomized complete block design with split plots. There were four replicates per treatment. Each experimental unit had an area of $60 \mathrm{~m}^{2}(6 \mathrm{~m} \times 10 \mathrm{~m})$. All the crops were sown using a dibber after tilling with a disc plough to a depth of $20 \mathrm{~cm}$ in the first year and directly beneath the plant cover in the following years. The plant cover used as mulch consisted of $S$. hamata biomass and millet crop residues produced at the site. All S. hamata biomass produced in the first year was used to create the mulch (between 187 and $1167 \mathrm{~kg} \mathrm{ha}^{-1}$ ), some of which was combined with millet stems (between 1680 and $2031 \mathrm{~kg} \mathrm{ha}^{-1}$ ). From the second year on, only onethird of the $S$. hamata biomass produced was left on the ground as litter along with all the millet residues. The quantities left as litter after the second year of cultivation are displayed in Table 1. The ground cover $(C)$ of the litter was estimated based on formula (1) (Scopel et al., 1999; Teasdale \& Mohler, 2000; Naudin et al., 2011):

$$
C=1-\exp ^{(-\operatorname{Am} \times M)}
$$

where $C$ denotes the cover rate (as a percentage), Am is the surface $/$ mass ratio $(A m=0.377$ for $S$. hamata and
Am $=0.367$ for millet stems), and $M$ is the mulch biomass (in tons).

Manual weeding occurred each year 15-21 days after sowing. To create satisfactory soil moisture conditions for S. hamata, which requires between 700 and $900 \mathrm{~mm}$ of rainfall per year, $150 \mathrm{~mm}$ (2012 and 2013) or $180 \mathrm{~mm}$ (2014) of water was divided into eight irrigation doses and applied over 28 days at the beginning of the cultivation period based on the delayed onset of the rainy season and/or rainfall frequency. The yield of the main crop was measured at harvest by weighing all the plot production.

\section{Data collection and processing}

The determination of $S$. hamata cover and identification of weed species were carried out according to the quadrat method in the third year of the rotation and at the end of the crops' vegetative cycle (in November). A transect was marked using measuring tape, which extended diagonally across the subplot. Observations were carried out every $20 \mathrm{~cm}$. At each point of observation, the identity of the plant species under the line of sight and the number of contacts, which indicates the number of intersections of an aboveground organ of the species with the line of sight, were recorded. The phytological parameters were determined based on these data (Daget \& Poissonet, 1974):

- the frequency $(\mathrm{Fi})$, which provides information about the coverage of a species (i) and is the ratio, expressed as a percentage of the number of times a species was observed to the total number of observation points;

- the specific contribution (SC) is the ratio, expressed as a percentage, of the frequency $(\mathrm{Fi})$ of the species to the total sum of the frequencies $(\Sigma \mathrm{Fi})$ of all the species, and it refers to the contribution of the species in the covering of the ground;

- the specific contact contribution (SCC) is the ratio, expressed as a percentage, of the number of contacts

Table 1. Estimated quantity of litter $\left(\mathrm{kg} \mathrm{ha}^{-1}\right)$ and cover rate (\%) obtained using one-third of the S. hamata biomass and all the millet stems produced after the second year of cultivation

\begin{tabular}{|c|c|c|c|c|c|c|}
\hline \multirow[t]{2}{*}{ Parameter } & & \multicolumn{5}{|c|}{ Crop rotations } \\
\hline & & SF-MS-GS & SF-GS-MS & GS-MS-GS & MS-GS-MS & MS-MS-MS \\
\hline \multirow[t]{2}{*}{ Quantity of mulch } & S. hamata & 320.10 & 398.25 & 527.20 & 143.20 & 304.90 \\
\hline & Millet stem ${ }^{\dagger}$ & 1269.40 & 0.00 & 1114.40 & 0.00 & 987.30 \\
\hline \multirow[t]{3}{*}{ Cover rate } & S. hamata & 11.36 & 13.93 & 18.02 & 5.25 & 10.86 \\
\hline & Millet stem ${ }^{\dagger}$ & 37.23 & 0.00 & 33.56 & 0.00 & 30.39 \\
\hline & Total & 48.59 & 13.93 & 51.58 & 5.25 & 41.25 \\
\hline
\end{tabular}

\footnotetext{
${ }^{\dagger}$ Full millet stem (with leaves)

(C) 2018 Weed Science Society of Japan
} 
for a given species to the sum of contacts for all the species; the SCC expresses the contribution of the species to the aboveground plant biovolume.

The structure of the flora was analyzed in each replicate using the Shannon-Weiner diversity index $(H)$ and the Shannon equitability (or frequency) index $(E)$. The diversity index, obtained using formula (2) and expressed in bits, ranges from 0 to 5 according to the diversity level. Evaluating equitability helps to detect changes in the structure of plant communities that are due to treatments. The equitability index, obtained using formula (3), ranges from 0 to 1 ; it indicates that a species is dominant if its value is close to 0 or the relatively balanced presence of several species if it is closer to 1 .

$$
\begin{gathered}
H=-\Sigma \mathrm{SCi} \cdot \log 2(\mathrm{SCi}) \\
E=H / \log 2(S)
\end{gathered}
$$

SCi - SC of species i;

$S$ - the number of species in the plant community.

The contribution of species to the biovolume is based on their SCC. The determination of this value provides an index for the production of each herbaceous species.

The aboveground biomass was estimated by harvesting the biomass in five $1 \mathrm{~m}^{2}$ quadrats randomly distributed across the subplot. Sorting occurred to separate the $S$. hamata biomass from that of the weed species, which were considered to be part of the same group. Two cross-sectional samples were taken, one in September and one between November and December. The first cross-sectional sample was intended to evaluate the effects of cutting and removal on the behavior of the crops and weed species. The final cross-sectional sample was taken after the weed species were identified, and it enabled the measurement of the total biomass.
Principal component analysis (PCA) and analysis of variance (ANOVA) were carried out on the specific frequencies of the species to evaluate their phytosociological behavior using Statistical Analysis Software (SAS). Tukey's HSD (Honestly Significant Difference) test enabled the comparison of averages of the different treatments. A Pearson adjustment test (chi squared test $-\chi^{2}$ ) was carried out to compare the distribution of weed species among treatments.

\section{RESULTS}

\section{Ground cover provided by litter and $S$. hamata vegetation}

The ground cover provided by litter after 3 years was low in all the rotations. Cover rates of 5.3 and $13.9 \%$ were estimated, respectively, for the MS-MS-MS and SF-GS-MS rotation plots, with mulch consisting solely of $S$. hamata. In the other rotations, the amount of ground cover provided by the litter (millet stems and $S$. hamata biomass) ranged between 41.3 and 51.6\% (Table 1). In the MS plots, millet stems provided $30-37 \%$ of the cover, whereas S. hamata biomass contributed between 5 and $18 \%$.

The cover provided by $S$. hamata vegetation remained high in all crop combinations, with cover rates of $84.3-93.3 \%$ after 3 years (Table 2). The ANOVA did not show any difference in the cover provided by $S$. hamata (Table 2) linked to the crop rotation $(P>0.05)$. However, planting $S$. hamata in combination with another crop seems to provide better cover and more consistent vegetation. Cutting back the aboveground biomass during growing season influenced the ground cover $(P<0.05)$ at the end of the cycle in the SF-MS-GS, SF-GS-MS and GS-MS-GS rotations.

Table 2. Vegetative soil cover by $S$. hamata (\%) measured at the end of the third year of cultivation in crop rotations according to the applied treatments

Fertilization Cutting back Crop rotations Average

\begin{tabular}{llcccccc} 
& & SF-MS-GS & SF-GS-MS & GS-MS-GS & MS-GS-MS & MS-MS-MS & \\
\hline \multirow{2}{*}{ AM } & Cut back & $75.00 \pm 14.57^{\mathrm{b}}$ & $83.00 \pm 8.17^{\mathrm{b}}$ & $85.50 \pm 5.59^{\mathrm{b}}$ & $80.00 \pm 5.20^{\mathrm{b}}$ & $87.00 \pm 12.59^{\mathrm{a}}$ & 82.10 \\
& Uncut & $93.50 \pm 7.06^{\mathrm{a}}$ & $95.50 \pm 3.15^{\mathrm{a}}$ & $99.00 \pm 1.05^{\mathrm{a}}$ & $92.00 \pm 8.33^{\mathrm{a}}$ & $99.50 \pm 0.75^{\mathrm{a}}$ & 95.90 \\
WAM & Cut back & $74.50 \pm 12.89^{\mathrm{b}}$ & $85.00 \pm 9.33^{\mathrm{b}}$ & $86.00 \pm 6.12^{\mathrm{b}}$ & $81.50 \pm 6.42^{\mathrm{b}}$ & $87.50 \pm 11.31^{\mathrm{a}}$ & 82.90 \\
& Uncut & $94.00 \pm 5.82^{\mathrm{a}}$ & $93.50 \pm 5.23^{\mathrm{a}}$ & $98.50 \pm 1.97^{\mathrm{a}}$ & $90.50 \pm 8.57^{\mathrm{a}}$ & $99.00 \pm 0.92^{\mathrm{a}}$ & 95.10 \\
Average & & $84.25^{\star}$ & $89.25^{\star}$ & $92.25^{\star}$ & $86.00^{\star}$ & $93.25^{\mathrm{NS}}$ & \\
\hline
\end{tabular}

$\star$ Significant difference $(P<0.05)$ between treatments.

Values with different letters show significant difference in the rotation. NS, no significant difference. 
Ground cover provided by $S$. hamata was reduced by $8-19 \%$ by mowing in all the treatments (Table 2 ).

The contribution of $S$. hamata to the biovolume was highly variable (Table 3). Cropping systems with $S$. hamata planted as improved fallow in the first year (SF-MS-GS and SF-GS-MS) made the lowest contributions to the biovolume during the third year (45.3 and $46.9 \%)(P<0.05)$. The values obtained with these cropping systems were not different from those obtained for MS-GS-MS (40.3\%). The contribution of $S$. hamata to the biovolume was higher for GS-MS-GS (55.4\%) and MS-MS-MS (57.5\%). These differences among treatments persisted even when the biomass was cut back during the vegetative period. However, the contribution of $S$. hamata to the biovolume was therefore $22-32 \%$ lower depending on the rotation.

\section{Floristic composition}

The weed flora were represented by 32 species belonging to 10 families. Grasses (Poaceae) and Fabaceae were the most represented, with 11 and 8 species, respectively. The other families were represented by one or two species (Table 4). These species were essentially therophytes, with the exception of Cyperus rotundus L. (Cyperaceae), which is a geophyte. As there was no clear difference in weed composition associated with animal manure application $\left(p\left\{\chi^{2}>\chi^{2}(\alpha, 124)\right\}=0.2\right)$, this factor is not shown in Tables 4 and 5 .

\section{Diversity of weed species}

The weed flora in the MS-MS-MS rotation included 22 weed species, whereas the other rotations included a slightly higher number of species (24 or 25). The floristic composition was more diverse in the subplots that were not cut back (18-22 species) than in the ones that were cut back (14-21 species). Eragrostis tremula, Eragrostis ciliaris, Dactyloctenium aegyptium, Digitaria ciliaris, Digitaria horizontalis and C. rotundus dominated in all plots. They accounted for $59-75 \%$ of the total population of weeds. The presence of species typical of environments that have hardly been disrupted or have been left untouched, such as Achyranthes aspera and Cassia mimosoides, was observed in all the rotations in which $S$. hamata had not been cut back, except for the MSMS-MS rotation. Weed species' diversity determined by the Shannon-Weiner diversity index $(\mathrm{H})$ was moderate (2.4-3.0) for the cut back treatments and high (3.1-3.5) for the ones that were not cut back (Table 5). Moreover, this reduction due to cutting back was more marked in the GS-MS-GS, MS-GS-MS and MS-MSMS rotations. Considering the rotation, the $H$ index was weaker in the MS-GS-MS sequence crop. Overall,

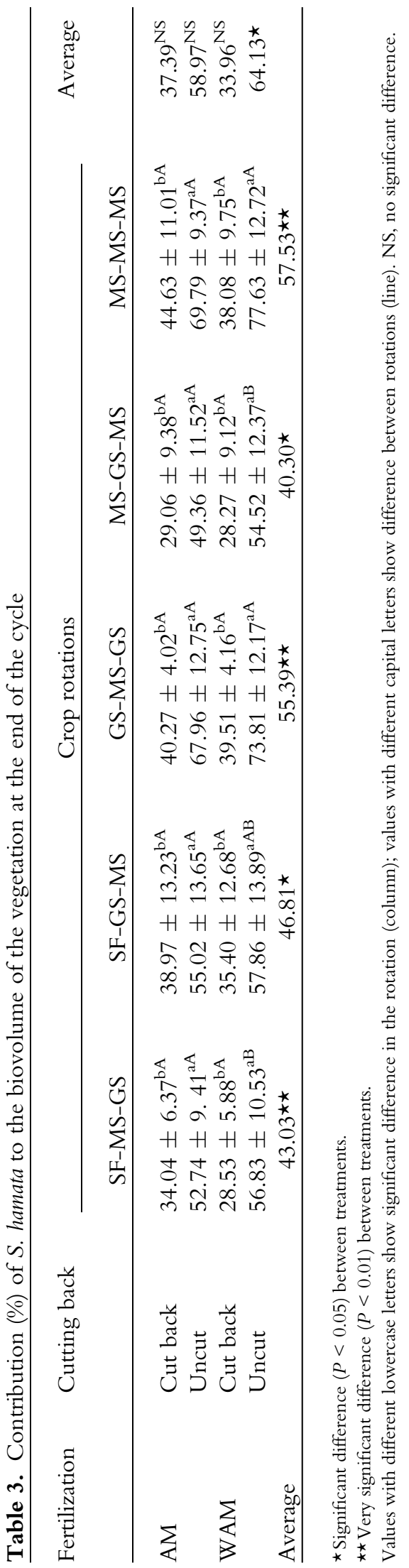




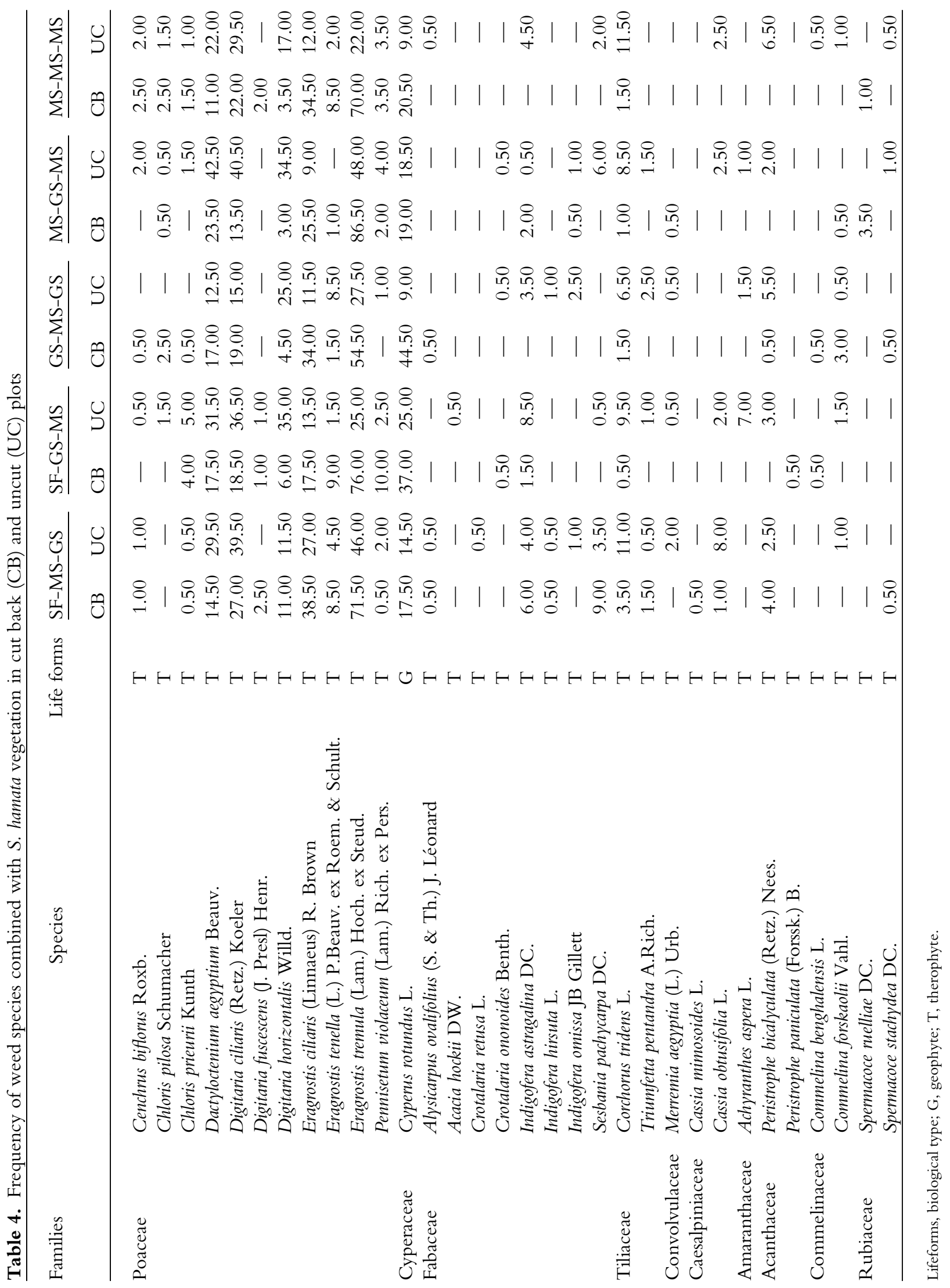


Table 5. Variation in the diversity $(\mathrm{H})$ and equitability $(\mathrm{E})$ indexes in the crop rotations

\begin{tabular}{llccccc}
\multirow{2}{*}{ Indices } & Cutting back & \multicolumn{5}{c}{ Crop rotations } \\
\cline { 3 - 6 } & & SF-MS-GS & SF-GS-MS & GS-MS-GS & MS-GS-MS & MS-MS-MS \\
\hline \multirow{2}{*}{ Diversity (H) } & Cut back & 3.00 & 2.80 & 2.70 & 2.40 & 2.80 \\
\multirow{4}{*}{ Equitability (E) } & Uncut & 3.30 & 3.50 & 3.50 & 3.10 & 3.50 \\
& Cut back & 0.70 & 0.70 & 0.70 & 0.60 & 0.70 \\
& Uncut & 0.80 & 0.80 & 0.80 & 0.70 & 0.80 \\
\hline
\end{tabular}

the equitability was high in all treatments and even higher when plants were not cut back.

Cutting back the vegetation after six weeks increased E. tremula abundance (data not shown), even though it reduced the number of weed species. In fact, the SC of this species increased by $9-26 \%$ in the different treatments after the vegetation was cut back, depending on the rotation. Conversely, the abundance of $D$. aegyptium and $D$. horizontalis declined after the biomass was cut back, and the SCs of these species fell by 5.6 and $10.6 \%$, respectively. The presence of perennial species, such as $A$. aspera and Corchorus tridens, was reduced $(P<0.05)$ by cutting back the vegetation.

\section{Contribution to biovolume and weed biomass}

The overall contribution of weed species to the biovolume varied depending on the treatment. It reached $40 \%$ on average for the GS-MS-GS and MS-MS-MS rotations. In the other rotations, it varied from 53.1 to $57 \%$. Cutting back the vegetation affected the contribution of weed species to the biovolume, which increased by $19-32 \%$. The dominant species in these populations, particularly E. tremula, E. ciliaris, D. aegyptium, D. ciliaris, D. horizontalis and C. rotundus, contributed $34.3-53.8 \%$ of the total biovolume. The contribution of E. tremula to the biovolume was even higher for treatments in which the vegetation had been cut back (between 27.1 and 47.9\%), unlike those that were not cut back, in which it amounted to 4.2 and $13.4 \%$ depending on the crop rotation.

The weed biomass varied considerably among treatments and within a treatment. It was, on average, 1465 and $851 \mathrm{~kg} \mathrm{ha}^{-1}$ in subplots that had not been cut back, with and without organic fertilizer, respectively. For subplots that had been cut back, the weed biomass was 2470 and $2243 \mathrm{~kg} \mathrm{ha}^{-1}$, respectively, with and without organic fertilizer. The comparison of the rotations only showed significant differences for the non-fertilized and uncut treatments (Table 6). The aboveground weed biomass was lower in the MS-GSMS crop sequence. For the same rotation, cutting back substantially increased the weed biomass with and without organic fertilizer. The biomass recorded for the crop sequences SF-GS-MS without any organic fertilizer and MS-GS-MS with and without organic fertilizer increased when the vegetation was cut back.

\section{Phytosociology of the weed species}

Although only $22 \%$ of the total variability was explained by the two first axes of the PCA (Fig. 1), it appears that the composition and structure of the weed flora were primarily driven by the cutting back treatment. Only the SF-MS-GS treatments that were cut back in Block 3 (T1F3), uncut SF-MS-GS in Block 1 (T1NF1), uncut MS-GS-MS in Block 3 (T4NF3) and uncut GS-MS-GS in Block 1 (T3NF1) had a different floristic composition and/or weed flora structure compared to the other treatments for the same treatment. The effects of one or more factors (rotation, fertilization and/or plant residues), other than cutting back, were more marked in the floristic composition of the "cut SF-MS-GS in Block 1" plot (T1F1).

Approximately 10 weed species were correlated with the PCA axes. The behavior of weed species, as shown on the factor map (Fig. 2), points to a strong correlation between the composition of the weed flora and axis 2 in the PCA, which is itself strongly correlated with the cutting back of vegetation. Cutting back the vegetation had an important role in the variability of E. tremula $\left(R^{2}=0.701\right)$, D. horizontalis $\left(R^{2}=0.586\right)$ and Pennisetum violaceum $\left(R^{2}=0.569\right)$ in the plots (Table 6). In addition, a negative correlation was found between E. tremula and most others species. For weed species such as Eragrostis tenella (Ete), Indigofera astragalina (Ias), Indigofera hirsuta (Ihu), C. mimosoides (Cmi), D. ciliaris (Dci) and Triumpheta pentandra (Tpe), rotation and/or fertilization factors seem to predominate. An important correlation appears between Digitaria fuscescens, E. ciliaris and E. tenella, showing the tendency of these species to cluster together. These species are negatively correlated with the main perennial species.

\section{Crop production and yield}

The yield of the main crop (millet or groundnut) is given in the Table 7 . It shows variations in millet yield 


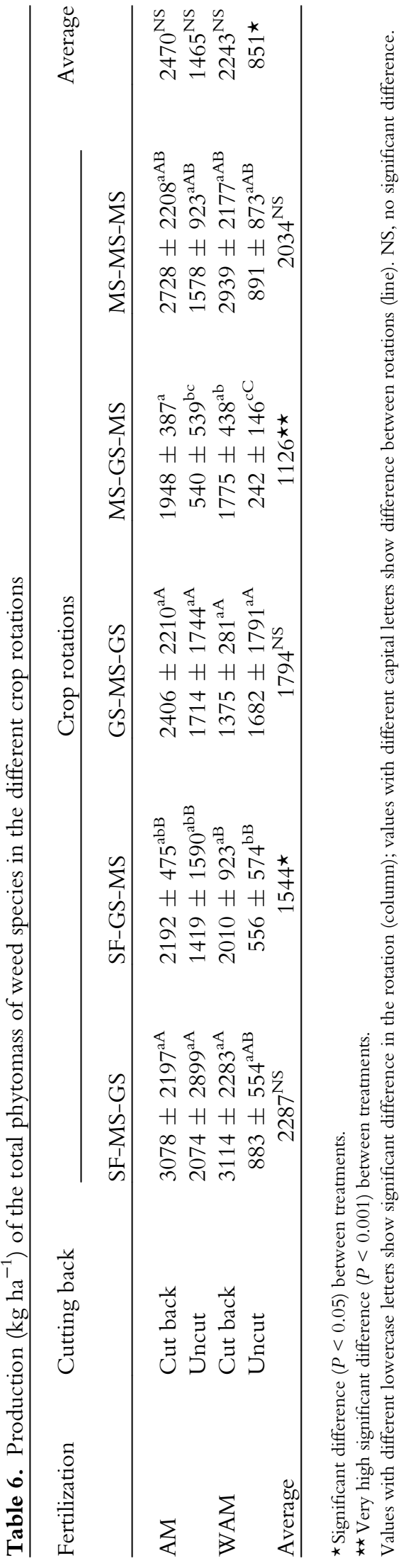

from a minimum of $17 \mathrm{~kg} \mathrm{ha}^{-1}$ in the MS-GS-MS rotation (uncut and zero-fertilizer treatment) to a maximum of $214 \mathrm{~kg} \mathrm{ha}^{-1}$ in the SF-GS-MS rotation (cutting back and fertilization treatment). Significant cumulative effects of AM and cutting back were observed on millet yield. Cutting back improves millet yield from 38 to $120 \%$, whereas yield increase attributed to AM varies from 59-228\%. The same trend was observed on the components of millet yield, especially the weight of 1000 seeds, which was significantly higher in AM and cutting back treatment $(5.1 \mathrm{~g})$ than WAM and uncut treatment $(4.7 \mathrm{~g})$.

Groundnuts yield was highly variable in the SF-MSGS rotation $\left(378-1053 \mathrm{~kg} \mathrm{ha}^{-1}\right)$ compared to the GSMS-GS rotation treatments $\left(627-903 \mathrm{~kg} \mathrm{ha}^{-1}\right)$. No clear effect of AM on groundnuts yield was found. However, a very significant effect of AM was observed on the weight of 100 seeds $(74.07 \mathrm{~g}$ for the treatment with AM versus $69.1 \mathrm{~g}$ for the treatment WAM). Cutting back positively affects the yield of groundnuts, with a $14-43 \%$ increase.

\section{DISCUSSION}

The results showed that there is no treatment for which mulching was sufficient to control weeds. Teasdale and Mohler (2000) recommend at least 90\% ground cover for controlling weeds. According to these authors, the range of values for weed suppression coefficients across mulches within a species is approximately 20-40-fold for mass. In our experiments, such a high ground cover rate could only be obtained for MS associations when all the cereal's aboveground biomass and $S$. hamata is used for mulch (Table 2). This option is not realistic. Due to the severe forage deficit in the dry season (Guérin et al., 1985), crop residues are a staple food source for cattle (Dièye \& Guèye, 1998). Using twothirds of $S$. hamata for animal feed considerably reduced the contribution of the legume to the soil cover but induced a higher yield of the associated crops due to a lower level of competition from the cut stylo cover compared to the uncut stylo treatments (data not shown). Considering the low efficacy of the tested mulch-based systems in controlling weeds and their negative consequences on crop yields, an alternative could be to carry out more stylo cuttings associated with manual weeding along the crop seeding line. This would allow weed control in crop row at an early vulnerable crop stage and reduce stylo and weed competition while increasing the availability of high-quality animal feed. In this system, only cereal stalks would be left on the soil after the harvest. However, in the MS 


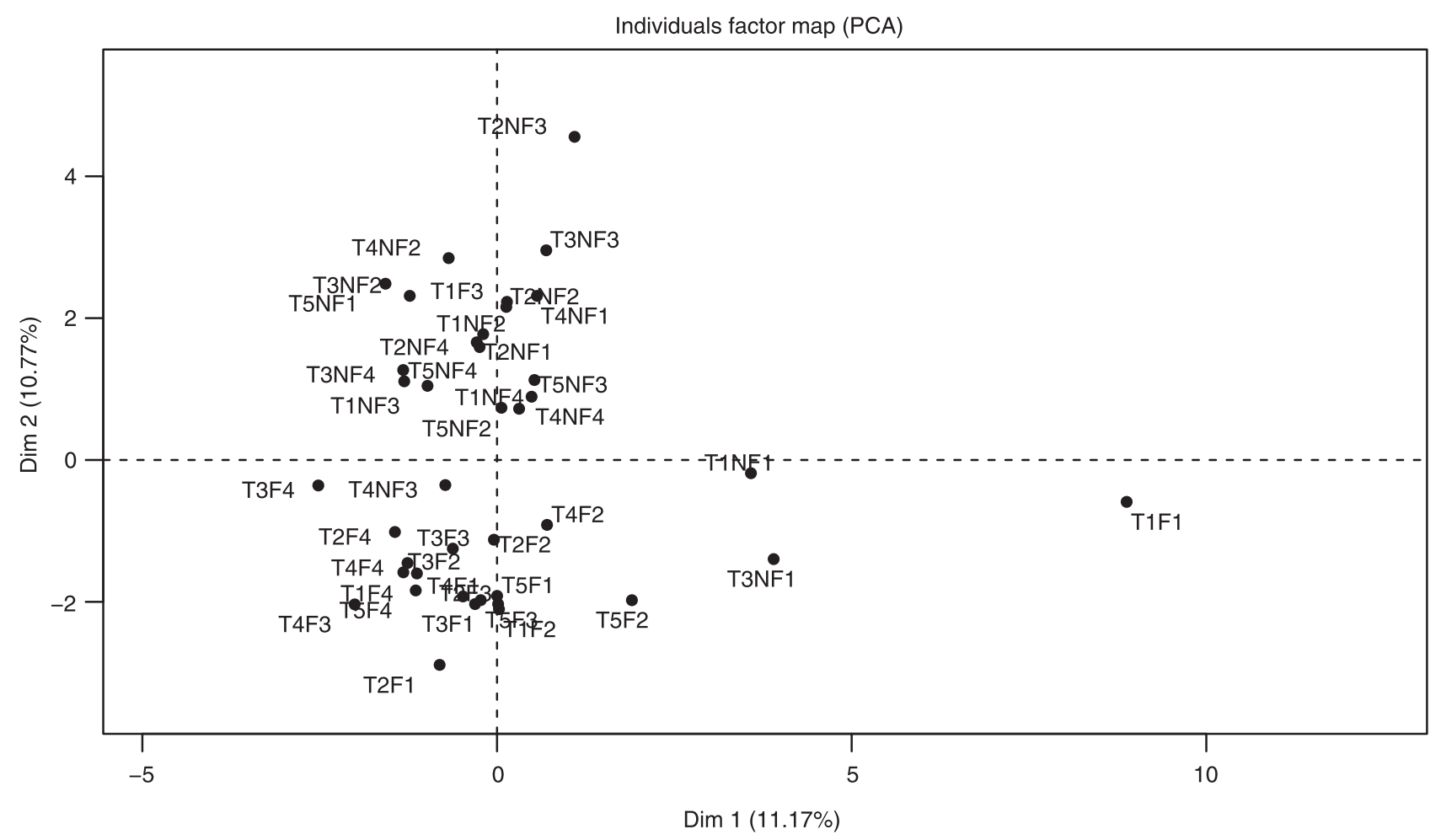

Fig. 1. Distribution map of plots based on the frequencies of weed species. T1, SF-MS-GS; T2, SF-GS-MS; T3, GSMS-GS; T4, MS-GS-MS; T5, MS-MS-MS; NF, Uncut; F, cutting back; $n(1 \leq n \leq 4)$, repeat (block); For example: T2NF3, plot in rotation SF-GS-MS, uncut in mid-season, in the repeat (block) 3.

treatments, over half of the soil can still be covered with millet stems, and $S$. hamata biomass is left on the field. Considering the results of previous studies (Teasdale \& Mohler, 2000; Naudin et al., 2011), the remaining litter will not be sufficient to control weeds, but it likely helps in improving the soil organic matter content and reducing soil erosion, which in turn could improve yields over the long term. Bilalis et al. (2003), quoted by Naudin et al. (2011), showed that low levels of ground cover (lower than or equal to 30\%) result in weed infestation levels comparable to those found in conventional cropping systems.

Although they provide important and consistent ground cover at the end of the cycle, $S$. hamata plants have proven to be ineffective at controlling weeds as they become established at the same time as undesirable species. Indeed, no-till approaches maintain weed seeds on the soil surface and promote their germination in the rainy season. The identified weed species are common in annual crop fields in Senegal's Sudano-Sahelian region (Noba, 2002). Species of low nutritional value, such as E. tremula (Skerman \& Riveros, 1990) and Cyperus spp., dominate in cleared plots, whereas species that are known to be productive and of high nutritional value, such as D. ciliaris (Skerman \& Riveros, 1990), are more common in uncut plots. These findings suggest that it should be possible to improve the production of quality forage in this type of cropping system by manipulating the cutting level of $S$. hamata. On-farm research could be carried out at the farm level to assess the acceptability of such practices.

The dominance of half a dozen species is reflected in the diversity and equitability indices. The dominance of annual species is in line with the results of Menalled et al. (2001) and Chauvel et al. (2011), which showed that refraining from ploughing promotes the development of annual species with low dormancy. These authors also observed the development of perennial species encouraged by the limitation of disruptionaffecting ecosystems that are not ploughed. In fact, the presence of $C$. mimosoides and $A$. aspera indicates that the plots were established on newly cleared land that has been extensively cultivated. In addition, considering that repeated weeding makes it possible to eliminate $A$. aspera, its existence in the plots indicates the limitations of the tested practices in terms of controlling it.

Weed management techniques, such as mowing aboveground biomass, influence weed species composition and abundance more than crop sequence. The effects of crop rotation on weed population seem to be 


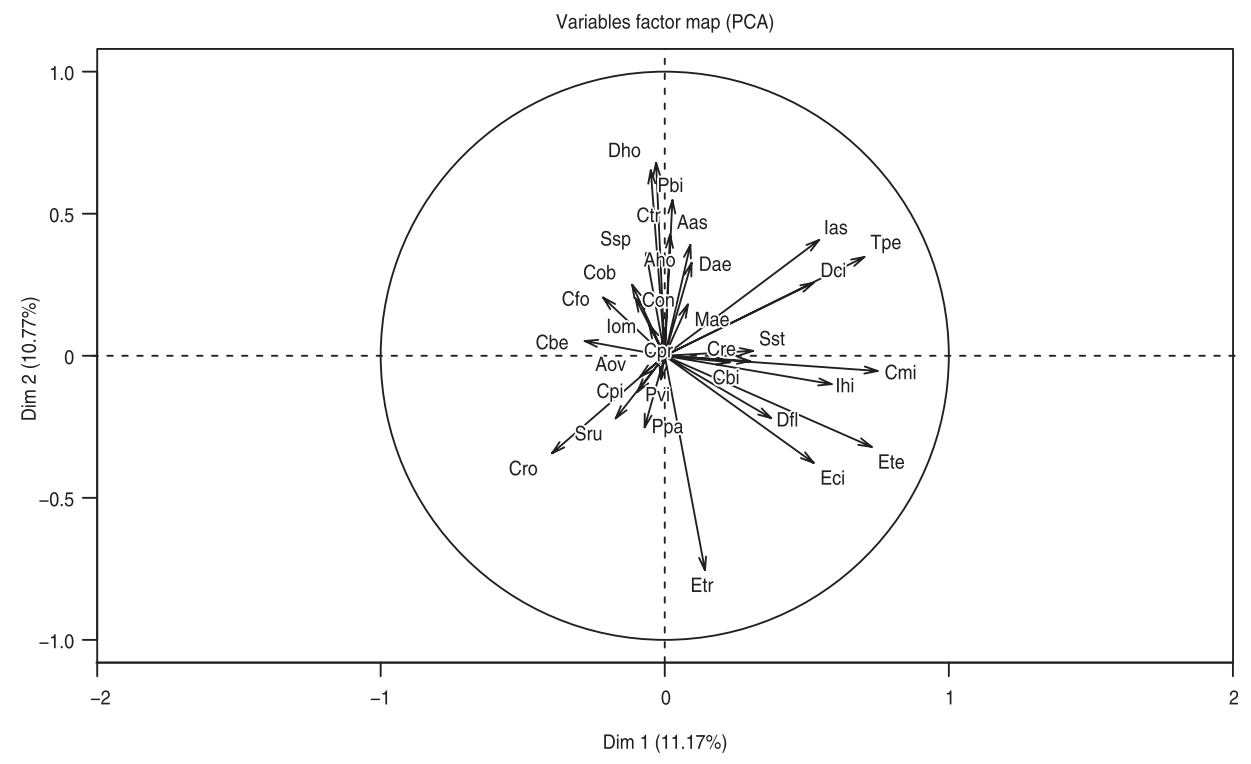

Fig. 2. Principal component analysis based on frequencies of weed species on plots. Aho, Acacia hockii DW.; Aas, Achyranthes aspera L.; Aov, Alysicarpus ovalifolius (S. \& Th.) J. Leonard; Cmi, Cassia mimosoides L.; Cob, Cassia obtusifolia L.; Cbi, Cenchrus biflorus Roxb.; Cpi, Chloris pilosa Schumacher; Cpr, Chloris prieurii Kunth.; Cbe, Commelina benghalensis L.; Cfo, Commelina forskaolii Vahl.; Ctr, Corchorus tridens L.; Con, Crotalaria ononoides Benth.; Cre, Crotalaria retusa L.; Cro, Cyperus rotundus L.; Dae, Dactyloctenium aegyptium Beauv.; Dci, Digitaria ciliaris (Retz.) Koeler; Dfl, Digitaria fuscescens (J. Presl) Henr.; Dho, Digitaria horizontalis Willd.; Eci, Eragrostis ciliaris (Linnaeus) R. Brown; Ete, Eragrostis tenella (L.) P.Beauv. Ex Roem. \& Schult; Etr, Eragrostis tremula (Lam.) Hoch. Ex Steud.; Ias, Indigofera astragalina DC.; Ihi, Indigofera hirsuta L.; Iom, Indigofera omissa JB Gillett; Mae, Merremia aegyptia (L.) Urb.; Pvi, Pennisetum violaceum (Lam.) Rich. ex Pers.; Pbi, Peristrophe bicalyculata (Retz.) Nees.; Ppa, Peristrophe paniculata (Forssk.) B.; Ssp, Sesbania pachycarpa DC.; Sru, Spermacoce ruelliae DC.; Sst, Spermacoce stachydea DC.; Tpe, Triumpheta pentandra A.Rich.

only significant in the long term (Menalled et al., 2001; Teasdale et al., 2004; Wortman et al., 2010). According to Teasdale et al. (2004), the rotations with the most phenologically diverse crops will result in the greatest decrease in weed population and abundance. The small variation in weed composition between rotations can be attributed to the permanent presence of $S$. hamata, which promotes biodiversity (Wortman et al., 2010).
Managing plant cover by cutting back and removing the aboveground biomass affects the structure of the flora without actually reducing weed infestation levels. Cutting back vegetation promotes the development of heliophilous weed species, such as E. tremula, while reducing the diversity of $D$. aegyptium, $D$. horizontalis and perennial species. Annual species usually have shallow root systems and require less effort in terms of

Table 7. Millet and groundnut yields $\left(\mathrm{kg} \mathrm{ha}^{-1}\right)$ measured in the third year of experimentation

\begin{tabular}{|c|c|c|c|c|c|c|}
\hline \multirow[t]{2}{*}{ Fertilization } & \multirow[t]{2}{*}{ Cutting back } & \multicolumn{5}{|c|}{ Crop rotations } \\
\hline & & SF-MS-GS & SF-GS-MS & GS-MS-GS & MS-GS-MS & MS-MS-MS \\
\hline \multirow[t]{2}{*}{ AM } & Cut back & $1053 \pm 565^{\mathrm{a}}$ & $214 \pm 130^{\mathrm{a}}$ & $722 \pm 273^{a}$ & $69 \pm 35^{\mathrm{a}}$ & $95 \pm 16^{\mathrm{a}}$ \\
\hline & Uncut & $887 \pm 383^{\mathrm{a}}$ & $98 \pm 54^{\mathrm{ab}}$ & $627 \pm 284^{a}$ & $54 \pm 32^{\mathrm{a}}$ & $53 \pm 25^{\mathrm{b}}$ \\
\hline \multirow[t]{2}{*}{ WAM } & Cut back & $761 \pm 201^{\mathrm{a}}$ & $66 \pm 13^{\mathrm{b}}$ & $903 \pm 506^{\mathrm{a}}$ & $29 \pm 20^{\mathrm{ab}}$ & $62 \pm 36^{\mathrm{ab}}$ \\
\hline & Uncut & $378 \pm 162^{\mathrm{b}}$ & $29 \pm 22^{c}$ & $797 \pm 119^{a}$ & $17 \pm 9^{b}$ & $31 \pm 12^{\mathrm{b}}$ \\
\hline Average & & $770 \star$ & $102 \star$ & $762^{\mathrm{NS}}$ & $42^{\star}$ & $60 \star \star$ \\
\hline
\end{tabular}

$\star$ Significant difference $(P<0.05)$ between treatments.

$\star \star$ Very high significant difference $(P<0.001)$ between treatments.

Values with different letters show significant difference in the rotation (column). NS, no significant difference. 
manual management. In fact, the plant cover provided by $S$. hamata greatly inhibits the germination of E. tremula seeds by reducing the incidence of radiation on the ground (Scopel et al., 1999; Teasdale \& Mohler, 2000; Noba, 2002). In addition, the more or less extended germination period of the species enables it to re-emerge after weeding. Conversely, D. aegyptium is a species that germinates early (Noba, 2002); it develops best if cover is provided due to the species' preference for mulch, possibly because of a stimulating effect of the mulch's allelochemicals (Poilecot, 1999). This ecological characteristic of the species is exploited in Kenya, where pastures seeded with D. aegyptium are covered with branches or mulch (Skerman et Riveros, 1990).

Over the long term, cutting back vegetation might have more marked effects on the diversity and structure of weed species. Menalled et al. (2001) showed that changes in the vegetation structure have a long-term effect on the diversity of species in seedbanks. Reducing the aboveground biomass by mowing during the most critical period of weed persistence can stifle the expansion of some weed species because some species produce very few seeds if the aboveground biomass is destroyed during this period (Ghersa et al., 2000). The study did not show any effects of organic fertilizer on the weed species composition or structure. This result could be explained by the experiment duration and the application of this factor only after the second year. Some authors (Teasdale et al., 2004) have shown that changes to the soil chemical conditions induced by the addition of organic manure over a long period affect the composition of the weed flora in organic farming cropping systems. In our trial, the increase in weed biomass in fertilized subplots was higher than that observed for $S$. hamata. This is consistent with the observations of Blackshaw et al. (2005), who report that weeds benefit from organic fertilizer application more than crops. An increase in weed infestation can be expected over time in these treatments if no measures are taken to limit their development.

The variations in yield can be explained by several factors, including the density of the main crop (millet or groundnut), the nuisance of $S$. hamata and weeds and the sensitivity of the crops to competition and to the growing conditions (organic manure, quantity of mulch, irrigation).

The low performances of production observed in the MS-MS-MS and MS-GS-MS rotation could be related to the density of $S$. hamata and of the weeds' higher and/or lower soil cover by mulch. Despite a corrective irrigation of $180 \mathrm{~mm}$, the particular low rainfall in 2014 (331 mm versus 767 in 2012 and $603 \mathrm{~mm}$ in 2013) was a major limiting factor to improve yield through AM.
The importance of sufficient rainfall for the efficiency of use of organic fertilizer by the crops has been reported by Buldgen et al. (1995). The water stress could have affected crop yield in two ways: increased competition between crops and companion crop or weeds resulting in poor filling of millet ears or pods and low mineralization of organic manure resulting in low availability of nutrients.

\section{CONCLUSION}

The direct-seeding mulch-based cropping systems tested in this experiment were characterized by major weed infestations despite annual weeding at the start of cultivation and despite the important ground cover provided by $S$. hamata at the end of the rainy season. Using two-thirds of the $S$. hamata biomass for animal feed considerably reduced the contribution of the legume to the soil cover, which was too low to control weeds in all the compared treatments. The diversity of the weed flora varied according to the crop rotation. However, management practices, such as mowing aboveground biomass, influence weed species' diversity and abundance more than crop rotation. The weed flora is dominated by several grass species and C. rotundus. The aboveground biomass management measures in the plots, such as cutting back and removing biomass, affected the structure and diversity of the weed flora without reducing the weed infestation level. They reduce perennial species and promote the development of heliophilous species. This modification of the weed flora structure could be beneficial in cases of minimal disturbance to the soil by weeding. Organic manure had a significant effect only on the overall weed biomass, which responds more favorably to organic fertilizer. We can assume that the increase in weed biomass caused by the application of manure will ultimately result in higher weed seed production. Consequently, the abundance and diversity of weed species might be affected by the addition of organic manure over the long term. Our work confirms that, under the conditions prevailing in the Groundnut Basin of Senegal, weed management in cropping systems without ploughing requires specific solutions that are tailored to the farmers' conditions and production targets. In this region, the use of herbicides is very scarce due to the low capacity of these farmers to buy them and the technical expertise required. The search for agricultural alternatives could focus on a long-term approach combining management practices such as crop rotation, mowing the aboveground biomass and weeding along the crop seeding line. Combined with cutting back the 
aboveground biomass, weeding the seeding line could be a compromise between slightly disturbing the soil and limiting the negative effects of weeds on crops.

\section{ACKNOWLEDGMENTS}

This work was sponsored by the Academy of Research and Higher Education of Belgium (Ex Inter-University Council of the French Community). We acknowledge the support of the National School of Agriculture (ENSA) of Thies (Senegal) for providing the experimental sites. Special thanks to Houda MOKRANI for her collaboration in the statistical analysis.

\section{DISCLOSURE STATEMENT}

The authors declare no conflicts of interest.

\section{REFERENCES}

Bilalis D., Sidiras N., Economou G. and Vakali C. 2003. Effect of different levels of wheat straw soil surface coverage on weed flora in Vicia faba crops. J. Agron. Crop Sci. 189, 233-241. https://doi.org/10. 1046/j.1439-037X.2003.00029.x.

Blackshaw R.E., Molnar L.J. and Larney F.J. 2005. Fertilizer, manure and compost effects on weed growth and competition with winter wheat in western Canada. Crop Prot. 24, 971-980. https://doi.org/10. 1016/j.cropro.2005.01.021.

Buldgen A., Piraux M. and Compère R. 1995. Réhabilitation des terres et synergie agriculture-élevage au sein de systèmes de production modernisés en région sahélo-soudanienne sénégalaise. In: L'homme peut-il refaire ce qu'il a défait ? Colloque et Congrès: Sciences et changements planétaire/Sécheresse. John Libbey Eurotext, Paris, 389-401.

Chauvel B., Tschudy C. and Munier-Jolain N. 2011. Gestion intégrée de la flore adventice dans les systèmes de culture sans labour. Cah. Agric. 20, 194-203.

Corbeels M., de Graaff J., Ndah T.H., Penot E., Baudron F., Naudin K. et al. 2014. Understanding the impact and adoption of conservation agriculture in Africa: a multi-scale analysis. Agric. Ecosyst. Environ. 187, 155-170. https://doi.org/10.1016/j.agee.2013.10.011.

Daget P. and Poissonet J. 1974. Quelques résultats sur les méthodes d'études phytoécologiques, la structure, la dynamique et la Typologie des prairies permanentes. Fourrage 59, 71-81.

Dièye P.N. and Guèye M. 1998. Les systèmes agriculture-élevage au Sénégal: importance, caractéristiques et contraintes. In: Workshop on Crop-Livestock in the Dry Savannas of West and Central Africa (IITA, Ibadan, 22-27 November 1998), 127-152.

Ekeleme F., Chikoye D. and Akobundu I.O. 2005. Weed seedbank response to planted fallow and tillage in southwest Nigeria. Agroforest. Syst. 63, 299-306. https://doi.org/10.1007/s10457-005-5747-0.

Fernandes P., Oliver R. and Diatta S. 2000. Changes in organic matter of a ferrallitic tropical soil degraded by cropping systems: the case of Southern Senegal. Arid Soil Res. Rehabil. 14, 137-150. https://doi. org/10.1080/089030600263067.

Ghersa C.M., Benech-Arnold R.L., Satorre E.H. and MartinezGhersa M.A. 2000. Advances in weed management strategies. Field Crop. Res. 67, 95-104.
Gruber S. and Claupein W. 2009. Effect of tillage intensity on weed infestation in organic farming. Soil Tillage Res. 105, 104-111. https:// doi.org/10.1016/j.still.2009.06.001.

Guérin H., Sall C., Friot D., Ahokpe B. and Ndoye A. 1985. Ébauche d'une méthodologie de diagnostic de l'alimentation des ruminants domestiques dans un système agropastoral: l'exemple de Thyssé Kaymor - Sonkorong au Sénégal. In: Communication présentée au séminaire, Relations Agriculture Elevage, DSA-CIRAD (MontpelIier, 10-13 Septembre 1985), 60-69.

Hani G. and Nawal A.-H. 2005. Weed seedbank response to tillage and crop rotation in semi-arid environment. Soil Tillage Res. 84, 184-191. https://doi.org/10.1016/j.still.2004.11.005.

Ito M., Matsumoto T. and Quinones M.A. 2007. Conservation tillage practice in sub-Saharian Africa: the experience of Sasakawa Global 2000. Crop Prot. 26, 417-423. https://doi.org/10.1016/j.cropro.2006. 06.017 .

Johansen C., Haque M.E., Bell R.W., Thierfelder C. and Esdaile R.J 2012. Conservation agriculture for small holder farming: opportunities and constraints of new mechanised seeding systems. Field Crop. Res. 132, 18-32. https://doi.org/10.1016/j.fcr.2011.11.026.

Légère A., Stevenson F.C. and Benoit D.L. 2005. Diversity and assembly of weed communities: contrasting responses across cropping systems. Weed Res. 45, 303-315. https://doi.org/10.1111/j.1365-3180.2005. 00459.x.

Menalled F.D., Gross K.L. and Hammond M. 2001. Weed aboveground and seedbank community responses to agricultural management systems. Ecol. Appl. 11, 1586-1601. https://doi.org/10.1890/1051-07 61(2001)011[1586:WAASCR]2.0.CO;2.

Mulugeta D. and Stoltenberg D.E. 1997. Weed and seedbank management with integrated methods as influenced by tillage. Weed Sci. 45, 706-715.

Muoni T., Rusinamhodzi L. and Thierfelder C. 2013. Weed control in conservation agriculture systems of Zimbabwe: identifying economical best strategies. Crop Prot. 53, 23-28. https://doi.org/10.1016/j.cropro. 2013.06.002.

Naudin K., Scopel E., Andriamandroso A.L.H., Rakotosolofo M., Andriamarosoa R.N.R.S., Rakotozandriny J.N. et al. 2011. Trade-offs between biomass use and soil cover. The case of rice-based cropping systems in the Lake Alaotra region of Madagascar. Exp. Agric. 48, 194-209.

Noba K. 2002. La flore adventice dans le sud du Bassin arachidier (Sénégal) : structure, dynamique et impact sur la production du mil et de l'arachide (Thèse de Doctorat d'état en Sciences Naturelles). Université Cheikh Anta Diop, Dakar-SENEGAL (2002), 128 p.

Odunze A.C. 2002. Mulching practice in a semi-arid zone of Nigeria for soil erosion control and grain yield of maize. J. Sustain. Agric. 20, 31-40. https://doi.org/10.1300/J064v20n02_05.

Poilecot P. 1999. Les Poaceae du Niger: description - illustration - ecologie utilisations. Boissiera, Vol. 56, Genève (1999), UICN-CIRAD, $766 \mathrm{p}$.

Razafimbelo T.M., Albrecht A., Basile I., Borschneck D., Bourgeon G., Feller C. et al. 2006. Effet de différents systèmes de culture à couverture végétale sur le stockage du carbone dans un sol argileux des Hautes Terres de Madagascar. Etud. Gest. Sols 13, 113-127.

Saito K., Azoma K. and Oikeh S.O. 2010. Combined effects of Stylosanthes guianensis fallow and tillage management on upland rice yield, weeds and soils in southern Benin. Soil Tillage Res. 107, 57-63. https://doi.org/10.1016/j.still.2010.03.001.

Salako F.K. and Tian G. 2003. Soil water depletion under various leguminous cover crops in the derived savanna of West Africa. Agric. Ecosyst. Environ. 100, 173-180. https://doi.org/10.1016/S0167-8809 (03)00191-9.

Scopel E., Chavez G.E. and Arreola T.J.M. 1999. Le semis direct avec paillis de résidus dans l'ouest mexicain: une histoire d'eau? Agric. Dévelop. 21, 71-86. 
Skerman P.J. and Riveros F. 1990. Tropical Grasses, vol. 23. Food \& Agriculture Organization of the United Nations, Rome.

Swanton C.J., Shrestha A., Knezevic S.Z., Roy R.C. and Ball-Coelho B. R. 2000. Influence of tillage type on vertical weed seedbank distribution in a sandy soil. Can. J. Plant Sci. 80, 455-457. https://doi. org/10.4141/P99-020.

Teasdale J.R. and Mohler C.L. 2000. The quantitative relationship between weed emergence and the physical properties of mulches. Weed Sci. 48, 385-392. https://doi.org/10.1614/0043-1745(2000)048 [0385:TQRBWE]2.0.CO;2.

Teasdale J.R., Mangum R.W., Radhakrishnan J. and Cavigelli M.A. 2004. Weed seedbank dynamics in three organic farming crop rotations. Agron. J. 96, 1429-1435. https://doi.org/10.2134/agronj2004.1429.
Valbuena D., Erenstein O., Homann-Kee Tui S., Abdoulaye T., Claesssens L., Duncan A.J. et al. 2012. Conservation agriculture in mixed crop-livestock systems: scoping crop residue trade-offs in sub-Saharan Africa and South Asia. Field Crop. Res. 132, 175-184.

Wortman S.E., Lindquist J.L., Haar M.J. and Francis C.A. 2010. Increased weed diversity, density and above-ground biomass in long-term organic crop rotations. Renew. Agric. Food Syst. 25, 281-295.

Zanin G., Otto S., Riello L. and Borin M. 1997. Ecological interpretation of weed flora dynamics under different tillage systems. Agric. Ecosyst. Environ. 66, 177-188. https://doi.org/10.1016/ S0167-8809(97)00081-9.

\section{(C) 2018 Weed Science Society of Japan}

